Pustaka Karya: Jurnal Ilmiah Ilmu Perpustakaan dan Informasi

Vol. 8 No. 2, Desember 2020, Hal. 75-84

http://dx.doi.org/10.18592/pk.v8i2.5132

ISSN (p) : 2089-5216 | ISSN (e) : 2723-7699

\title{
Perpustakaan digital, koleksi digital dan undang-undang hak cipta ${ }^{1}$ Siti Wahdah \\ ${ }^{1}$ Dosen Program Studi Ilmu Perpustakaan dan Informasi Islam UIN Antasari Banjarmasin \\ ${ }^{1}$ Jalan A. Yani KM. 4.5, Kota Banjarmasin, Kalimantan Selatan 70235 \\ e-mail: ${ }^{1}$ wahdahsiti01@gmail.com
}

\begin{abstract}
Librarians as digital library managers need to pay attention to issues related to digital collections, including legal and regulatory issues related to intellectual property rights or copyrights related to taking and making digital collections and plagiarism. This research is a qualitative type with a descriptive approach. The data was obtained using a literature study technique by searching the latest journal articles and books. By using four stages, namely data collection, data reduction, data presentation and the last step is drawing conclusions and verification. In connection with the copyright, in accordance with the provisions of the library legislation, in carrying out the task of digitizing the collection, there will be no problem and conflict with the legal provisions of copyright as long as the purpose is only for educational and research purposes, and not for commercial purposes. Libraries as information processing institutions can make institutional regulations to address copyright issues related to legal issues such as regulations: Deposit Trade-Secrecy, Copy Left, Doktrin Fair Use.
\end{abstract}

Keywords: copyright; digital library; digital collection; librarian

\begin{abstract}
ABSTRAK
Pustakawan sebagai pengelola perpustakaan digital perlu memperhatikan isu-isu yang terkait dengan koleksi digital di antaranya isu-isu hukum dan perundan-undangan yang berkaitan dengan hak kekayaan intektual atau hak cipta yang terkait dengan pengambilan dan pembuatan koleksi digital dan plagiarisme. Penelitian ini berjenis kualitatif dengan pendekatan deskriptif. Data didapat menggunakan Teknik studi pustaka dengan menelusur artikel jurnal dan buku mutakhir. Dengan menggunakan empat tahap yaitu pengumpulan data, reduksi data, penyajian data dan langkah terakhir adalah penarikan kesimpulan dan verifikasi. Berkaitan dengan hak cipta tersebut sesuai dengan ketentuan perundang-undangan perpustakaan dalam melaksanakan tugas digitalisasi koleksi tidak akan bermasalah dan bertentangan dengan ketentuan hukum dari hak cipta selama tujuan tersebut hanya sebatas untuk kepentingan pendidikan dan penelitian, dan bukan untuk kepentingan komersial. Perpustakaan sebagai lembaga pengelolah informasi bisa membuat peraturan-peraturan lembaga untuk mengatasi maslah hak cipta yang berkaitan dengan masalah hukum seperti peraturan: Peraturan Deposit Trade-Secrecy, Copy Left, Doktrin Fair Use.
\end{abstract}

Kata Kunci: hak cipta; koleksi digital; perpustakaan digital; pustakawan

\section{PENDAHULUAN}

Era gelobalisasi dan kemajuan teknologi dalam bidang informasi, penemuan jaringan internet serta informasi digital, telah memberikan dampak positif yang sangat besar dalam dunia perpustakaan. Salah satu bentuk kemajuan perpustakaan di bidang teknologi informasi adalah pembangunan perpustakaan digital. Qalyubi (Qalyubi, 2007) menjelaskan bahwa perpustakaan digital adalah penerapan atau penggunaan teknologi digital untuk memperoleh, menyimpan, melestarikan, dan menyediakan akses terhadap informasi dan materi-materi yang diterbitkan dalam bentuk digital 
atau didigitalisasikan dari bentuk tercetak, audio visual, dan bentuk-bentuk lainnya. Menurut Digital Library Federation pengertian perpustakaan digital adalah "that provide the resources, including the specialized staf, to select, structure, offer intellectual access to, interpret, distribute, preserve the integrity of, and ensure the persistence over time of collections of digital works so that they are readily and economically available for use by a defined community or set of communities".

Dengan demikian, berdasarkan pada definisi diatas, pada dasarnya perpustakaan digital tidak ubahnya seperti perpustakaan konvensional hanya saja memiliki kelebihan dari objek-objek yang mendasar meliputi koleksi digital, staf pengelola perpustakaan digital, komunitas pengguna perpustakaan.

Perpustakaan digital bisa dianggap sebagai institusi informasi dalam bentuk baru atau sebagai perluasan dari pelayanan perpustakaan yang sudah ada. Perpustakaan digital sebagai koleksi informasi yang dikelola, yang memiliki pelayanan terkait, informasinya disimpan dalam format digital dan dapat diakses melalui jaringan. Perpustakaan dalam membangun infrastruktur jaringan elektronik atau digital dipengaruhi oleh beberapa faktor, yaitu 1) eksternalitas pada tingkat sosial, seperti penerapan hukum pada kekayaan intelektual (copyright), investasi dalam infrastruktur komunikasi nasional; 2) keterbatasan lembaga dan organisasi lokal, seperti ketersediaan sumber daya, kebutuhan pengguna, kepemimpinan seseorang dalam mengatur organisasi; 3) terobosan teknologi informasi merubah kebiasaan sosial dan kerja dalam skala besar (Yuadi, 2007).

Melalui penyediaan sumber-sumber informasi digital, perpustakaan dapat mengembangkan program yang memungkinkan para penggunanya untuk mengakses basis data perpustakaan. Mengingat pentingnya sumber-sumber informasi digital ini sejumlah perpustakaan perguruan tinggi dalam beberapa tahun terakhir ini bekerja keras untuk meningkatkan kapasitas informasi elektronik atau digital mereka, apakah itu berupa jurnal elektronik (e-journal), e-theses, edisertations, atau buku-buku elektronik (e-books) lainnya, baik yang disajikan secara utuh (full text) maupun sebagian (abstrak)-nya saja. Dilihat dari segi legalitas dari suatu jenis ciptaan atau koleksi yang didigitalkan.

Pembangunan perpustakaan digital tidak hanya berhenti pada penyediaan koleksi digital beserta infrastruktur pendukungnya. Pustakawan sebagai pengelola perpustakaan digital juga perlu memperhatikan isu-isu terkait dengan koleksi digital yang dimiliki. Adapun isu-isu yang menghadang dalam pengembangan perpustakaan digital biasa di kelompokkan menjadi 1) isu teknologi tentang apa yang dilakukan berkaitan dengan akuisisi dan pemindahan menjadi media digital.. Isu-isu organisasi: Bagaimana organisasi menanggapi perubahan peran dan tanggungjawab, baik yang berkaitang dengan Sumber Daya Manusia (SDM); 2) isu-isu ekonomi tentang siapa yang penanggung biaya dan akankah ada skala ekonomi; dan 3) isu-isu hukum dan perundan-undangan yang berkaitan dengan hak kekayaan intektual yang terkait dengan pengambilan dan pembuatan koleksi digital dan plagiarism.

Pernyataan diatas terdapat beberapa isu-isu yang dihadapi perpustakaan dalam mengembangkan perpustakaan digital diantaranya yang berkaitan dengan hak cipta koleksi digital yang dimiliki dan plagiarisme. Dengan demikian akan dibahas mengenai langkah-langkah pembangunan perpustakaan digital serta isu-isu yang terkait dalam pengembangan koleksi digital. 


\section{TINJAUAN PUSTAKA}

\section{A. PENGERTIAN PERPUSTAKAAN DIGITAL}

Sebelum membahas lebih mendalam tentang koleksi digital terhadap pelangaran hak cipta dan plagiatisme, akan dijelaskan terlebih dahulu istilah dari perpustakaan digital dan pengertian digital yang dikemukan oleh para ahli.

Istilah perpustakaan digital adalah terjemahan langsung dari 'digital libraries', sebuah istilah yang lahir dan berkembang di Amerika Serikat dan menyebar secara cepat ke seluruh dunia. Ketika istilah ini mulai popular di Indonesia muncul beberapa pendapat yang bila dilihat secara umum memiliki dua titik ekstrim. Pada titik ekstrim pertama adalah pandangan yang menganggap bahwa perpustakaan digital adalah sesuatu yang baru sama sekali dan tidak punya hubungan apa-apa dengan, perpustakaan biasa, atau 'perpustakaan tradisional'.

Menurut Dian Wulandari konsep perpustakaan digital adalah sebagai perpustakaan elektronik yang informasinya didapat disimpan diperoleh kembali melalui format digital. Sedangkan menurut Ismail Fahmi perpustakaan digital adalah sebuah sistem yang terdiri dari perangkat keras dan perangkat lunak, koleksi elektronik, staf pengolah, pengguna, organisasi, mekanisme kerja serta layanan, dengan memanfaatkan berbagai jenis teknologi informasi.

Berdasarkan definisi perpustakaan digital diatas dapat disimpulkan bahwa perpustakaan digital merupakan sebuah sistem yang telah teorganisasi, yang terdiri dari perangkat keras, perangkat lunak, koleksi elektronik, dan staf yang akan bertanggung jawab untuk menghimpun dan mengolah perpustakaan digital, dan kemudian sistem tersebut terhubungkan dengan jaringan internet, yang memberikan kemudahan dan keleluasaan kepada pengguna dalam mengakses perpustakaan digital/mengakases koleksi digital.

\section{B. PEMBANGUNAN PERPUSTAKAAN DIGITAL}

Pendit (Pendit, 2007) mengatakan bahwa pembangunan perpustakaan digital di pendidikan tinggi idealnya memperhatikan tiga aspek penting 1) aspek organisasional yakni mencakup permasalahan tata kehidupan perguruan tinggi sebagai masyarakat pengguna jasa perpustakaan, persoalan pengaturan sumber daya informasi, dan pengelolaan sumber daya manusia dalam konteks manajemen perpustakaan secara keseluruhan; 2) aspek mekanisasi, otomatisasi, dan komunikasi informasi. Pada aspek ini pustakawan diajak untuk mengenali ciri-ciri dasar dari masingmasing teknologi dan bagaimana memanfaatkan ciri-ciri tersebut bagi pengelolaan organisasi perpustakaan yang baru; 3) aspek legalitas yakni aspek legal dan etis dari penggunaan teknologi baru di masyarakat.

Sebagai sebuah masyarakat modern, perpustakaan memerlukan pengaturan tentang hak dan kewajiban dalam cara menyajikan, menyimpan, menyebarkan dan menggunakan informasi dalam kegiatan pendidikan tinggi. Berbagai aspek tersebut sepantasnya menjadi perhatian bagi semua pihak yang terkait dengan keberadaan suatu informasi elektronik, baik pengguna sistem (user), pengembang sistem (developer), dan penyelenggara sistem (operator) serta pihak yang memiliki kewenangan untuk mengawasi dan membina penyelenggaraan sistem agar dapat melindungi kepentingan publik.

\section{PROBLEMATIKA HAK CIPTA}

Penyediaan sumber-sumber informasi digital, perpustakaan dapat mengembangkan program yang memungkinkan para penggunanya untuk mengakses basis data perpustakaan. Mengingat pentingnya sumber-sumber informasi digital ini sejumlah perpustakaan perguruan tinggi dalam beberapa tahun terakhir ini bekerja keras untuk meningkatkan kapasitas informasi elektronik atau digital mereka, apakah itu berupa jurnal elektronik (e-journal), e-theses, edisertations, atau buku- 
buku elektronik (e-books) lainnya, baik yang disajikan secara utuh (full text) maupun sebagian (abstrak)-nya saja. Dilihat dari segi legalitas dari suatu jenis ciptaan atau koleksi yang didigitalkan, Wahono (Wahono, 1999) menyebutkan ada beberapa faktor penghambat di antaranya 1) hak cipta pada dokumen yang didigitalkan. Kegiatan di dalamnya adalah merubah dokumen tercetak ke dokumen digital, memasukkan dokumen digital ke database, merubah dokumen digital ke format Hypertext Markup Language (HTML); 2) hak cipta pada dokumen di jaringan komunikasi. Di dalam hukum hak cipta masalah transfer dokumen atau koleksi lewat jaringan komputer belum didefinisikan dengan jelas. Hal yang perlu disempurnakan adalah tentang hak menyebarkan, hak meminjamkan, hak memperbanyak, hak menyalurkan baik kepada masyarakat umum atau pribadi. Semua transfer datanya memanfaatkan media jaringan komputer termasuk di dalamnya internet, intranet, dan sebagainya; 3) masalah penarikan biaya. Hal ini menjadi masalah terutama untuk perpustakaan digital swasta yang menarik biaya untuk setiap dokumen yang diakses maupun yang dicetak. Namun, dalam prakteknya perpustakaan juga sangat sulit untuk menerapkan peraturan hak cipta secara optimal.

Seperti halnya yang dikatakan oleh Tri-Wahyu dalam Wahid (Nashihuddin, 2009) bahwa penerapan hak cipta di perpustakaan tidak dapat berjalan optimal karena disebabkan oleh beberapa alasan di bawah ini 1) ketidaktahuan pengguna tentang hak cipta, dapat dibuktikan dengan banyaknya permintaan foto kopi keseluruhan buku; 2) penjelasan yang kurang lengkap dari petugas perpustakaan tentang hak cipta membuat pengguna merasa tidak mempunyai beban untuk membuat salinan keseluruhan isi buku; 3) pelanggaran hak cipta menjadi tanggung jawab moral pengguna, karena merekalah yang memanfaatkan salinan perbanyakan dengan alasan apapun; 4) tidak adanya sanksi yang tegas terhadap pelanggaran hak cipta di perpustakaan, karena di UU Hak Cipta sendiri juga tidak menyatakan secara jelas tentang pemanfaatan koleksi di perpustakaan; 5) terbatasnya terbitan yang ada di perpustakaan, sehingga mengharuskan pengguna memperbanyak sendiri dengan menggunakan jasa perpustakaan; 6) tuntutan kebutuhan pengguna dalam penguasaan ilmu pengetahuan dan teknologi, sehingga pengetahuan tersebut harus disebarluaskan kepada masyarakat luas; 7) pendidikan moral dan faktor ekonomi yang menyebabkan perpustakaan lebih bijak menyikapinya; 8) tuntutan layanan prima kepada pengguna, jika aturan hak cipta terlalu kaku maka perpustakaan akan ditinggalkan pengguna.

Berkaitan dengan permasalahan di atas, Pendit (Pendit, 2007) mengatakan bahwa ketentuan hukum mengenai hak cipta adalah tidak adil bagi sebagian pihak, termasuk juga tidak adil bagi perpustakaan. Hal itu terjadi karena pihak perpustakaan beranggapan bahwa lembaga-lembaga informasi yang besar saja, seperti halnya penerbit buku dan agen-agen informasi ternama yang mengambil keuntungan terbanyak dari materi-materi yang dilindungi hak cipta, dan bukan para pencipta karya tersebut.

\section{METODE PENELITIAN}

Penelitian ini bertujuan untuk melihat fenomena perpustakaan digital dan koleksi digital dari sudut pandang undang-undang hak cipta yang kini semakin ramai dalam diskursus ilmu perpustakaan dan informasi. Untuk mendapatkan hasil yang diinginkan, maka penelitian ini akan berjenis penelitian kualitatif dengan menggunakan pendekatan deskriptif. Adapun teknik yang digunakan untuk mengumpulkan data, menggunakan teknik studi pustaka dengan menelusur informasiinformasi yang komprehensif di dalam artikel-artikel jurnal maupun buku-buku terkait tema penelitian.

Setelah data didapatkan, kemudian data dianalisis dengan empat tahap yaitu pengumpulan data, reduksi data, penyajian data dan langkah terakhir adalah penarikan kesimpulan dan verifikasi. Agar data yang didapat lebih akurat, peneliti menggunakan teknik triangulasi data yakni mengecek kembali data-data yang didapat melalui sumber-sumber referensi lain, mengecek kembali data dari 
sumber melalui teknik yang berbeda dan mengecek kembali data yang didapatkan dalam waktu yang berbeda.

IV. HASIL DAN PEMBAHASAN

\section{A. PENGOLAHAN KOLEKSI DIGITAL BERKAITAN DENGAN HAK CIPTA}

Menjawab pertanyaan di atas dalam mengelola koleksi digital sesuai dengan prosedur dan kaedah etis penggandaan koleksi digital. Penerapan kaidah ini erat kaitannya dengan perlindungan hakhak privasi dari masyarakat di dalam dunia digital. Sebagaimana yang dijelaskan dalam mengelola sumber-sumber koleksi digitalnya, khusunya karya hasil penelitian dan jurnal, hendaknya perpustakaan lebih memperhatikan empat prinsip tentang kaedah atau aturan digitalisasi seperti halnya yang dikatakan oleh Pendit (Pendit, 2007) yaitu:

\section{Privasi}

Menyangkut kerahasiaan berarti masalah keamanan database koleksi digital, maka pada sistem jaringan perpustakaan digitalnya ditanami sistem keamanan (mosesax). Pihak perpustakaan juga memberikan batasan-batasan terhadap koleksi local content yang akan diakses, misalnya pengguna tidak dapat men-download file-nya. Tujuannya agar tidak terjadi penjiplakan atau pembajakan ciptaan digital secara besarbesaran.

\section{Properti}

Mengenai kewajiban serah karya cetak dan rekam yang sudah diserahkan ke perpustakaan adalah milik sepenuhnya perpustakaan, karena sudah ada kesepakatan atau lisensi di atas surat pernyataan terlebih dahulu.

\section{Akurasi atau Keaslian}

Hal ini diatur dalam Pasal 25 ayat 1 UU Hak Cipta No.19 Tahun 2002 bahwa: "informasi elektronik tentang informasi manajemen hak pencipta tidak boleh ditiadakan atau diubah”. Berdasarkan pasal tersebut, maka perpustakaan dalam mendigitalkan koleksi tetap mencantumkan identitas penulis aslinya, dan tugas perpustakaan hanya mempublikasikan informasi. Misalnya, untuk keaslian identitas si penulis, dalam setiap halaman koleksi digital di bagian footer diberi tanda copyrigth atau “@”.

\section{Hak Akses}

Semua koleksi local content dapat diakses secara bebas dan dapat dibaca secara keseluruhan (full text). Akan tetapi, pengguna tidak dapat men-download file digital tersebut karena berkaitan dengan aspek keaslian dari identitas si penulis karya digital.

Terdapat asumsi menarik dari permaslahan di atas hal yang menarik bahwa perpustakaan dalam melaksanakan tugas digitalisasi koleksi tidak akan bermasalah dan bertentangan dengan ketentuan hukum dari hak cipta selama tujuan tersebut hanya sebatas untuk kepentingan pendidikan dan penelitian, dan bukan untuk kepentingan komersial. Pernyataan tersebut juga ditegaskan dalam Pasal 15 point (a) UU Hak Cipta No.19 Tahun 2002 sebagaimana berbunyi; “Penggunaan ciptaan pihak lain untuk kepentingan pendidikan, penelitian, penulisan karya ilmiah, penulisan kritik atau tinjauan suatu masalah dengan tidak merugikan dari pencipta”.

Dengan kata lain, jika lembaga informasi atau perpustakaan akan melakukan pendigitalan suatu dokumen atau koleksi dengan tujuan dan kepentingan yang lain, hendaknya lebih berhati-hati agar nantinya tidak berujung pada hukuman, denda dan sanksi pidana bagi perpustakaan. "contoh, jika pengguna akan memanfaatkan koleksi tersebut dengan cara men-download file suatu karya hendaknya teregistrasi lebih dulu sesuai dengan persyaratan yang telah ditentukan oleh perpustakaan”. 
Pendit (Pendit, 2007) menambahkan bahwa pengguna yang akan men-download dokumen digital hendaknya harus memperhatikan dua syarat 1) mewajibkan pelaku download untuk memberikan alamat e-mail asli; 2) mewajibkan pelaku download menyetujui perjanjian penggunaan (user agreement) atau perjanjian lisensi (license agreement) dari setiap isi informasi digital yang hendak di download, sampai dengan menggunakan sarana-sarana kontrol teknologi untuk menyaring penggunaan isi yang tidak sah.

Asumsinya bahwa setiap ide, gagasan, maupun pikiran yang sudah tertuang dalam bentuk karya intelektual/koleksi adalah dilindungi hak cipta, baik itu berbentuk koleksi cetak (printed) maupun elektronik (digital). Sehingga agar aman dari pelanggran hak cipta, perpustakaan harus menyiapkan beberapa perangkat atau peraturan terulis yang isinya memuat kesepakatan dan lisensi diantara kedua belah pihak. Dengan pernyataan bahwa setiap koleksi/informasi yang sudah diterima perpustakaan itu adalah hak prerogrratif perpustakaan untuk mengalihmediakan koleksinya ke bentuk apapun tanpa adanya komplain/protes dari si penulis karya.

Pernyataan tertulis itu bisa dijadikan peraturan maupun kebijakan perpustakaan untuk melindungi setiap koleksi yang dikelolanya. Beberapa kebijakan yang diberikan perpustakaan dalam mengelola sumber daya digital antara lain peraturan deposit, trade-secrecy, copy left, dan doktin fair use.

Mengenai peraturan dalam mengelola sumber-sumber koleksi digital yang menyangkut hak cipta, sekali lagi penulis tegaskan bahwa lembaga pengelola pusdokinfo belum memiliki peraturan itu, tetapi dalam proses digitalisasi koleksinya masih mengikuti peraturan perpustakaan pada umumnya. Seperti halnya yang telah diterapkan perpustakaan digital di Amerika, telah memiliki peraturan tentang Digital Right Management Systems (DRMS) yang berfungsi untuk mengontrol penyebaran dan penggunaan buku elektronik/digital perpustakaan, di mana dalam prakteknya penerapan hak ciptanya juga berbeda dengan koleksi tercetak.

Pendit (Laxman Pendit, 2008) mengatakan bahwa lembaga DRMS tersebut bernama Copyright Management Center yang bertugas untuk 1) melindungi hak cipta semua karya digital yang disimpan di dalam perpustakaan digital mereka; 2) mencakup hak dan kewajiban mahasiswa dalam menggunakan koleksi digital perpustakaan. Dengan demikian, hak penulis dan pencipta dapat terlindungi oleh hukum hak cipta, sehingga para penulis atau pencipta karya lebih untuk menciptakan karya-karyanya yang lebih kreatif. Serta, segala bentuk penjiplakan dalam proses digitalisasi koleksi atau setiap karya intelektual dapat dihindari oleh perpustakaan.

Dari pemaparan di atas, secara tegas penulis kemukakan bahwa permasalahan mengenai digitalisasi koleksi belum diatur sepenuhnya oleh UU Hak Cipta. Tetapi, penulis anggap bahwa ciptaan atau koleksi dikelola oleh lembaga informasi atau perpustakaan merupakan suatu bentuk karya intelektual hasil pengalihwujudan. Koleksi hasil pengalihwujudan dari karya cetak ke karya elektronik atau digital penulis menyebutnya dengan koleksi digital, yang sudah seharusnya dilindungi oleh UU Hak Cipta. Sebagaimana halnya tercantum dalam Pasal 12 ayat 1 point (l) UU Hak Cipta No.19 Tahun 2002 menyatakan bahwa: “dalam undang-undang ini ciptaan yang dilindungi adalah ciptaan dalam bidang ilmu pengetahuan, seni, dan sastra yang mencakup: karya terjemahan, tafsir, saduran, bunga rampe, database, dan karya lain dari hasil pengalihwujudan”.

Seiring pemberlakuan UU Hak Cipta No.19 Tahun 2002 pada tanggal 29 Juli 2003, lembaga informasi dan instansi pendidikan yang mengelola suatu ciptaan atau informasi sudah sepantasnya memperhatikan segala ketentuan UU Hak Cipta tersebut. Berdasarkan ketentuan yang ada di UU Hak Cipta tersebut, siapa saja yang akan memanfaatkan suatu ciptaan atau koleksi orang lain harus 
mendapatkan izin dari pencipta atau pemilik karya intelektual tersebut. Penjelasan tersebut juga dikuatkan dalam Pasal 49 UU Hak Cipta No.19 Tahun 2002 yang menyebutkan bahwa; ”pelaku memiliki hak eksklusif untuk memberikan izin atau melarang pihak lain yang tanpa persetujuannya membuat, memperbanyak, atau menyiarkan suara dan/atau gambar pertunjukaannya”.

Menurut UU Hak Cipta tersebut segala aktivitas yang berkaitan dengan penggunaan, perbanyakan, dan penyebaran informasi di dalam jaringan komputer (internet) itu diperbolehkan, selama ada izin dan lisensi yang jelas dari pencipta atau pemilik aslinya. Salah satu cara yang ditempuh untuk menghindari pelanggaran tersebut adalah diperlukan adanya suatu tatanan sosial atau penerapan kaedah etis dalam pengelolaan koleksi digital yang dikenal dengan kaidah penggandaan (copy norms).

\section{B. PENGOLAHAN KOLEKSI DIGITAL BERDASARKAN LEMBAGA}

Pengolahan koleksi digital memerlukan sebuah peraturan yang jelas karena hal ini berkaitan dengan pelangaran hukum terhadap hak cipta. peraturan yang bisa diterapkan pada perpustakaan perguruan tinggi meliputi:

\section{Peraturan deposit}

Menurut Sulistiyo-Basuki (Basuki, 1991) UU Deposit adalah undang-undang yang mewajibkan setiap penerbit atau pencetak mengirimkan contoh terbitannya (biasanya dua eksemplar atau lebih) ke perpustakaan nasional atau perpustakaan lain yang ditunjuk. Tidak hanya koleksi tercetak saja yang diatur dalam peraturan tersebut, kini juga mewajibkan mengirimkan koleksi terekam seperti kaset, piringan hitam dan lembaran musik.

Namun, dalam prakteknya istilah UU Deposit tidak dapat dilaksanakan secara maksimal oleh lembaga perpustakaan, karena ketentuan dan peraturan normatifnya bersifat universal, dan itupun hanya berlaku untuk Perpustakaan Nasional. Padahal, di masing-masing jenis perpustakaan memiliki peraturan dan kebijakan yang berbeda-beda, serta fungsi perpustakaan dalam melayankan informasinya juga berbeda. Termasuk juga bagi Perpustakaan Perguruan Tinggi, undang-undang tersebut sangat sulit untuk diterapkan. Dengan memiliki kebijakan khusus, Perpustakaan Perguruan Tinggi dapat membuat dan mengeluarkan peraturan deposit, di mana memiliki konteks dan isi yang bersifat lokal dan kondisional.

Dengan kata lain bahwa peraturan deposit tersebut disesuaikan dengan kebutuhan kapasitas perpustakaan dalam mengelola sumber-sumber informasinya. Peraturan deposit berisi kewajiban bagi pencipta dan sekaligus pengguna untuk menyerahkan karya ciptanya, baik karya cetak atau karya rekam sesuai dengan yang ditentukan oleh perpustakaan. Kewajiban serah simpan karya cetak dan karya rekam yang diatur dalam peraturan ini bertujuan untuk mengembangkan sumbersumber informasi unggulan pada perpustakaan dan melestarikannya sebagai hasil budaya bangsa dalam rangka mencerdaskan kehidupan bangsa. Jadi, dengan peraturan deposit yang dibuat oleh perpustakaan akan memiliki kebijakan dan peraturan khusus, tanpa adanya penekanan dari hak cipta.

Menurut Sulistiyo-Basuki (Basuki, 1991) ketika peraturan deposit dikaitkan dengan hak cipta maka dalam menggandakan ciptaan satu kopi harus memiliki izin terlebih dulu dengan ketentuan sebagai berikut 1) kopi tersebut digunakan bukan untuk mencari untung, tetapi dibuat oleh perpustakaan untuk kepentingan umum, serta harus ada tanda copyright "(C)" pada kopi ganda; 2) untuk karya yang tidak diterbitkan maka kopi tersebut berlaku sebagai kopi pelestarian atau sebagai substitusi bagi peminjaman ke luar perpustakaan; 3) kopi untuk menggantikan kopi asli yang hilang atau rusak, apabila perpustakaan tidak dapat memperoleh gantinya dengan harga wajar; 4) bagi artikel yang diperoleh dari perpustakaan lain maka kopi artikel tersebut hanya boleh digunakan untuk keperluan pribadi serta harus mencantumkan ketentuan hak cipta. 
Terkait dengan pencantuman tanda copyright dari setiap karya, baik yang karya cetak maupun digital memiliki cara dan strategi yang khusus. Hakim (2009) mengatakan bahwa ada beberapa strategi yang dapat dilakukan oleh lembaga informasi atau perpustakaan dalam mendapatkan dan mencantumkan tanda copyright pada koleksi digital, yaitu 1) perpustakaan dapat mengirimkan surat kepada pengarang, penerbit atau pemegang hak cipta suatu karya agar memberikan izin kepada perpustakaan mendigitalkan hasil karyanya; 2) perpustakaan sering mendapatkan sumbangan laporan penelitian, makalah atau publikasi lainnya. Perpustakaan dapat menyodorkan surat perjanjian yang berisi kesediaannya penyumbang memberikan izin kepada perpustakaan untuk mendigitalkan hasil penelitian atau makalah yang disumbangkan kepada perpustakaan. Di dalam surat perjanjian tersebut juga dimuat pernyataan bahwa perpustakaan akan ikut melindungi hak cipta dari pengarang bersangkutan; 3) perpustakaan juga dapat melengkapi koleksi digital perpustakaan dengan mencari koleksi digital berlabel open content di internet. Open content ini memungkinkan masyarakat memanfaatkan suatu dokumen tanpa perlu takut akan hak cipta yang melekat didalamnya karena penulis atau pemilik hak cipta karya tersebut memberikan kebebasan kepada masyarakat untuk mengakses dan memanfaatkan hasil karnyanya; 4) perpustakaan harus menentukan standar file koleksi digital yang tidak memungkinkan orang untuk merubah isi dari koleksi digital. Standar file koleksi digital tersebut adalah file dalam format PDF. Stardar file jenis ini tidak memberikan kesempatan seseorang untuk melakukan editing file sehingga keaslian file tersebut dapat terjaga.

\section{Trade-secrecy}

Trade-secrecy adalah pembatasan akses informasi pada sebuah organisasi yang biasanya dilakukan dengan penandatanganan persetujuan sebelumnya. Jelasnya peraturan ini adalah suatu peraturan perjanjian tentang pembatasan hak akses organisasi perpustakaan dalam memanfaatkan hak milik intelektual orang lain. Beberapa cara umum digunakan dalam mengontrol hak cipta pada sebuah akses informasi dalam perpustakaan digital yaitu 1) menyediakan formulir perjanjian antara lembaga dan penulis. Penulis harus menyetujui hasil karyanya dipublikasikan secara digital oleh perpustakaan sesuai dengan aturan dan perjanjian yang berlaku; 2) mengedit hasil karya dengan menambahkan informasi pencipta karya tersebut, sesuai dengan persetujuan yang telah ditetapkan; 3) membatasi akses pengguna terhadap dokumentasi tertentu, misalnya file tertentu hanya bisa dibaca dan tidak bisa di-copy atau didownload (Suprihadi, 2005).

\section{Copy left}

Perpustakaan harus memahami hak cipta sebagai landasan kebijakan pengikat informasi digitalnya, perpustakaan juga dapat mengembangkan copy left sebagai lawan dari copyright (hak cipta). Jika copyright umumnya digunakan untuk melarang penggunaan karya intelektual tanpa seizin dari pemegang hak ciptanya, maka copy left justru memastikan bahwa setiap orang yang memperkaya intelektual tersebut dapat menggunakan, memodifikasi, dan juga meredistribusi baik karya yang asli atau karya turunannya.

Dalam istilah copy left, si pencipta tidak menjelmakan hak ekonomisnya namun tetap menegakkan hak moralnya, yaitu hak pencantuman nama dalam ciptaannya. Kandungan copy left yaitu sekumpulan lisensi yang diberikan pada setiap orang yang memiliki kopi suatu karya ilmiah untuk menjamin agar orang tersebut dapat menjalankan hak ekonomi atas karya tersebut (menggandakan, menyebarluaskan, memodifikasi) dengan syarat karya tersebut dan turunannya disebarkan dengan lisensi yang sama. Lisensi dalam copy left menjamin bahwa setiap pemilik dari kopi suatu karya digital dapat melakukan tiga hal yaitu menggunakannya tanpa pembatasan apapun, meredistribusikannya sebanyak apapun yang diinginkan, dan memodifikasinya dengan cara apapun yang dianggap memungkinkan (Pendit, 2007). 


\section{Doktrin fair use}

Terdapat pengecualian tentang ketentuan hukum mengenai hak cipta memungkinkan penggunaan suatu ciptaan tanpa seizin dari pemegang haknya sepanjang tidak merugikan kepentingan yang wajar dari si_pencipta. Pengecualian tersebut bersifat limitatif dan hanya berlaku terhadap apa-apa yang tercantum dalam UU Hak Cipta. Konsepsi pengecualian ini disebut dengan doktrin penggunaan yang wajar atau fair use doctrine (Pendit, 2007).

Menurut Pendit (Pendit, 2007) terdapat beberapa bentuk pengecualian doktrin fair use terhadap koleksi digital juga diatur dalam Pasal 15 UU Hak Cipta No.19 Tahun 2002, yang mana menyatakan bahwa "sumbernya harus disebutkan atau dicantumkan", dan tidak dianggap sebagai pelanggaran hak cipta bila 1) penggunaan ciptaan pihak lain untuk kepentingan pendidikan, penelitian, dan penulisan karya ilmiah dengan tidak merugikan kepentingan yang wajar dari pencipta; 2) pengambilan ciptaan pihak lain, baik seluruhnya atau sebagian, guna keperluan ceramah, pertunjukan dan pementasan untuk tujuan pendidikan dan ilmu pengetahuan, serta tidak memungut biaya yang merugikan pencipta; 3) perbanyakan suatu ciptaan bidang ilmu pengetahuan, seni, dan sastra dalam huruf Braille guna keperluan para tunanetra, kecuali jika perbanyakan itu bersifat komersial; 4) pembuatan salinan cadangan suatu program komputer oleh pemilik program komputer yang dilakukan semata-semata untuk digunakan sendiri.

\section{KESIMPULAN}

Dari uraian diatas dapat disimpulkan bahwa pengembagan perpustakaan digital berkaitan dengan koleksi digital masih mengalami beberapa permasalahan mengenai digitalisasi koleksi yang belum diatur sepenuhnya oleh UU Hak Cipta. Tetapi, penulis beranggapan bahwa ciptaan atau koleksi dikelola oleh lembaga informasi atau perpustakaan merupakan suatu bentuk karya intelektual hasil pengalihwujudan. Koleksi hasil pengalihwujudan dari karya cetak ke karya elektronik atau digital seperti UU Hak Cipta. Sebagaimana halnya tercantum dalam Pasal 12 ayat 1 point (l) UU Hak Cipta No.19 Tahun 2002 menyatakan bahwa "dalam undang-undang ini ciptaan yang dilindungi adalah ciptaan dalam bidang ilmu pengetahuan, seni, dan sastra yang mencakup: karya terjemahan, tafsir, saduran, bunga rampe, database, dan karya lain dari hasil pengalihwujudan”. Selain itu perpustakaan sebagai lembaga pengelolah informasi bisa membuat peraturan-peraturan lembaga untuk mengatasi maslah hak cipta yang berkaitan dengan masalah hukum seperti peraturan: Peraturan Deposit Trade-Secrecy, Copy Left, Doktrin Fair Use.

\section{DAFTAR PUSTAKA}

Basuki, S. (1991). Pengantar ilmu perpustakaan. Gramedia Pustaka Utama. https://books.google.co.id/books?id=3GeZAAAACAAJ

Cornish, Graham P. 2004. Copy right: Interpreting the Law for Libraries, Archives and Information Services. London: Facet Publishing.

Giri P, EM. 2008. Undang-Undang HAKI: Hak Atas Kekayaan Intelektual. Jakarta: Visimedia.

Laxman Pendit, P. (2008). Perpustakaan Digital dari A sampai Z. Jakarta.

Nashihuddin, W. (2009). PENGELOLAAN KOLEKSI DIGITAL MENURUT UNDANG UNDANG HAK CIPTA (STUDI ANALISIS DI PERPUSTAKAAN UIN SUNAN KALIJAGA YOGYAKARTA). https://doi.org/10.13140/RG.2.2.10904.03847

Pendit, P. L. (2007). Perpustakaan Digital: Perspektif Perpustakaan Perguruan Tinggi Indonesia. Sagung Seto. 
Qalyubi, S. (2007). Dasar-dasar ilmu perpustakaan dan informasi. Yogyakarta: Jurusan Ilmu Perpustakaan dan Informasi (IPI), Fakultas Adab UIN Sunan Kalijaga.

Suprihadi, E. (2005). Digitalisasi Informasi Karya Ilmiah dan Perlindungan Karya Intelektual. Makalah dalam Seminar Online Informasi Resource Sharing dan Digitalisasi Karya Ilmiah di Lingkungan Perguruan Tinggi, Universitas Negeri Malang.

Wahono, R. S. (1999). Digital Library dan Proyek-Proyek Penelitiannya dan Proyek-Proyek Penelitiannya. DIimensi, 2(1).

https://www.academia.edu/8006533/Digital_Library_dan_Proyek_Proyek_Penelitiannya _dan_Proyek_Proyek_Penelitiannya

Yuadi, I. (2007). Perpustakaan digital: Paradigma, konsep dan teknologi informasi yang digunakan. Jurnal Jurusan Ilmu Informasi dan Perpustkaan FISIP UnairSurabaya, 2835. 